\title{
PENGARUH STRATEGI KOMUNIKASI DAN EFEKTIVITAS PESAN PROGRAM GENRE TERHADAP PENGETAHUAN DAN SIKAP REMAJA DI KECAMATAN CARINGIN
}

\section{THE INFLUENCE OF COMMUNICATION STRATEGIES AND MESSAGES EFFECTIVENESS OF THE GENRE PROGRAM ON YOUTH KNOWLEDGE AND ATTITUDES IN CARINGIN SUB-DISTRICT}

\author{
Samhatul Nurmila ${ }^{1 a}$, Rita Rahmawati $^{2}$, Agustini $^{3}$ \\ 1,2,3 Jurusan Ilmu Komunikasi, Fakultas Ilmu Sosial dan Ilmu Politik, Universitas Djuanda \\ Jl. Tol Ciawi No.1 Kotak Pos 35 Bogor 16720.
}

a Korespondensi: Samhatul Nurmila, Email: $\underline{\text { samhatul.nurmila@unida.ac.id }}$

(Diterima: 18-01-2017; Ditelaah: 25-3-2016; Disetujui: 28-03-2017)

\begin{abstract}
This study focuses on the communication strategy and the effectiveness of the Program GenRe message conducted by DP3AP2KB Bogor District. The purpose of this study was to determine the effect of communication strategy and the effectiveness of the Program Message GenRe DP3AP2KB Bogor to the knowledge and attitude of adolescents in District Caringin. Methode used was associative by using a quantitative approach. Samples taken amounted to hundred people, with Simple Random Sampling technique. Technique of collecting data is done by using literature study, observation, interview and dispersion of questionnaire, then the data obtained was analyzed by using Weigh Mean Scoredan followed by Rank Spearman. The results of this study indicate that there was a positive influence between independent variables (communication strategy and messaging effectiveness of GenRe Program) on the dependent variable (knowledge and attitude of adolescent). Results of correlation coefficient analysis obtained value of $0.412 * *$ which means having a moderate relationship with coefficient of $17 \%$. Thus it can be concluded that Communication Strategy and Messages Program Effectiveness GenRe socialized by the Office of Women Empowerment and Perlindungam Anak, Control Population and Family Planning Has been an influence on the Knowledge and Attitude of Youth in Caringin Sub-district
\end{abstract}

Keywords : Communication Strategy, Communication Effectiveness, Program

\begin{abstract}
ABSTRAK
Penelitian ini memusatkan perhatian pada strategi komunikasi dan efektivitas pesan Program GenRe yang dilakukan oleh DP3AP2KB Kabupaten Bogor. Tujuan dari penelitian ini yaitu untuk mengetahui pengaruh strategi komunikasi dan efektivitas pesan Program GenRe DP3AP2KB Kabupaten Bogor terhadap pengetahuan dan sikap remaja di Kecamatan Caringin.Metode yang digunakan adalah asosiatif dengan menggunakan pendekatan kuantitatif. Sampel yang diambil berjumlah 100 orang, dengan teknik Simple Random Sampling. Teknik pengumpulan data dilakukan dengan menggunakan studi kepustakaan, observasi, wawancara dan penyebaran angket, kemudian data yang diperoleh dianalisis dengan menggunakan Weigh Mean Scoredan dilanjutkan dengan Rank Spearman. Hasil peneltian ini menunjukkan terdapat pengaruh positif antara variabel independen (strategi komunikasi dan efektivitas pesan Program GenRe) terhadap variabel dependen (pengetahuan dan sikap remaja). Hasil analisis koefisien korelasi diperoleh nilai sebesar $0,412^{* *}$ yang berarti memiliki hubungan yang sedang dengan nilai koefisien sebesar 17 \%.Dengan demikian dapat disimpulkan bahwa Strategi Komunikasi dan Efektivitas Pesan Program GenRe yang disosialisasikan oleh Dinas Pemberdayaan
\end{abstract}


Perempuan dan Perlindungam Anak, Pengendalian Penduduk dan Keluarga Berencana memiliki pengaruh terhadap Pengetahuan dan Sikap Remaja di Kecamatan Caringin

Kata Kunci: Strategi Komunikasi, Efektivitas Komunikasi, Program.

Samhatul Nurmila, Rita Rahmawati, Agustini, 2017. Pengaruh Strategi Komunikasi dan Efektivitas Pesan Program GenRe Terhadap Pengetahuan dan Sikap Remaja di Kecamatan Caringin. Jurnal Komunikatio 3(1): 29-36. 


\section{PENDAHULUAN}

Salah satu aspek kemajuan suatu negara dapat dilihat dari kualitas remajanya, karena remaja sebagai generasi muda merupakan bibit unggul, penerus dan pewaris bangsa memiliki peranan penting dalam membangun negara.Namun pada kenyataannya, kualitas remaja sekarang ini sudah semakin terkikis dengan adanya kemajuan era globalisasi diberbagai bidang khususnya teknologi yang menimbulkan banyak terjadinya kenakalan dan pergaulan bebas remaja.

Melihat berbagai fakta yang terjadi saat ini, tidak sedikit para remaja yang terjerumus ke dalam lembah seksualitas, narkoba bahkan terkena HIV dan AIDS yang dapat menghancurkan masa depan remaja dan secara otomatis merubuhkan pula kualitas bangsa dalam suatu negara. Remaja Kabupaten Bogor menjadi salah satu contoh fenomena yang terjadi dalam kasus kenakalan remaja saat ini.

Dalam hal ini, perlu adanya perubahan sebagai bentuk proses untuk memperbaiki kualitas remaja.Pemerintah selain menjadi fungsi pengaturan juga berperan sebagai fungsi pembinaan. Pada Pemerintah daerah kabupaten atau kota, fungsi pembinaan dilaksanakan oleh badan atau dinas tersendiri. Di Kabupaten Bogor, fungsi pembinaan dilakukan oleh Dinas Pemberdayaan Perempuan dan Perlindungan Anak, Pengendalian Penduduk dan Keluarga Berencana (DP3AP2KB).Bentuk upaya yang dilakukan oleh DP3AP2KB Kabupaten Bogor untuk mewujudkan remaja yang berkualitas yaitu dengan dibentuknya sebuah program penginformasian pesan.

Salah satu strategi yang dirumuskan oleh DP3AP2KB Kabupaten Bogor dalam hal pembentukan kualitas remaja yaitu melalui sosialisasi pesan pada Program GenRe (Generasi Berencana) dengan fokus sasaran kepada remaja usia 10-24 tahun yang belum menikah. Program GenRe bertujuan untuk memfasilitasi terwujudnya remaja yang berprilaku sehat, terhindar dari resiko TRIAD KRR (Tiga Ancaman Dasar Kesehatan Reproduksi Remaja) yang meliputi pernikahan dini, seks sebelum menikah dan napza (narkotika, psikotropika, zat adiktif lainnya). Selain itu remaja dapat melakukan pendewasaan usia perkawinan serta bertujuan untuk mewujudkan keluarga kecil bahagia dan sejahtera.

\section{Tinjauan Teori}

\section{StrategiKomunikasi}

Strategi komunikasi merupakan paduan dari perencanaan komunikasi dan manajemen komunikasi untuk mencapai tujuan yang telah tetapkan, Effendy (2009).

Dalam rangka menyusun strategi komunikasi diperlukan suatu pemikiran dengan memperhitungkan faktor-faktor pendukung dan faktor-faktor penghambat yang dapat dilihat dari empat dimensi berikut:
1. Sasaran Komunikasi
2. Media Komunikasi
3. Tujuan Pesan
4. Peranan Komunikator

\section{Efektivitas Komunikasi}

Steward L. Tubbs (2010) mengemukakan bahwa komunikasi dapat dikatakan efektif apabila ada lima indikasi berikut:

1. Pengertian, penerima yang cermat dari isi stimulasi seperti apa yang dimaksud oleh komunikator.

2. Kesenangan, komunikasi ini juga disebut dengan komunikasi fasis (phatic communication) yang dimaksud untuk menimbulkan kesenangan. Komunikasi menjadi hubungan antar individu menjadi hangat, akrab dan menyenangkan.

3. Pengaruh pada sikap, komunikasi juga sering dilakukan untuk mempengaruhi orang lain, seperti seorang khotib yang ingin membangkitkan sikap keagamaan dan mendorong jamaah dapat beribadah dengan baik, atau seorang politisi yang ingin menciptakan citra yang baik kepada public pemilihnya. 
4. Hubungan sosial yang makin baik, komunikasi juga ditunjukkan untuk menumbuhkan hubungan sosial yang baik. Manusia adalah makhluk sosial yang tidak dapat bertahan hidup sendiri, untuk itu manusia selalu berkeinginan untuk berhubungan dengan orang lain secara positif.

5. Tindakan, tindakan persuasi dalam komunikasi digunakan untuk mempengaruhi sikap persuasif, juga diperlukan untuk memperoleh tindakan yang dikehendaki komunikator.

\section{Program GenRe}

GenRe atau Generasi Berencana adalah program yang dikembangkan oleh BKKBN (Badan Kependudukan dan Keluarga Berencana Nasional) untuk memfasilitas terwujudnya Tegar Remaja, yaitu remaja yang berprilaku sehat, terhindar dari resiko TRIAD KRR dan merencanakan keluarga kecil bahagia sejahtera.

Ciri-ciri tegar remaja tersebut yaitu dengan mendewasakan usia pernikahan, berprilaku sehat, terhindar dari resiko Napza, Seksualitas, HIV dan AIDS, bercitacita mewujudkan keluarga kecil bahagia dan sejahtera, serta menjadi contoh, model, idola, dan sumber informasi bagi teman sebayanya.

GenRe diperlukan karena berperan sebagai sumber informasi yang berkaitan dengan penyiapan diri remaja untuk menyongsong kehidupan berkeluarga yang lebih baik, menyiapkan pribadi yang matang dalam membangun keluarga yang harmonis serta memantapkan perencanaan dalam menata kehidupan untuk keharmonisan.

\section{Pengetahuan Remaja}

Sarigih (2007) dijelaskan bahwa definisi pengetahuan adalah kepercayaan yang benar (knowledge is justified true belief). Sedangkan secara terminology menurut Gazaba (1992) dalam Sarigih (2007) pengetahuan adalah apa yang diketahui atau hasil pekerjaan tahu. Notoatmodjo
(2005) mendefinisikan pengetahuan adalah hasil penginderaan manusia, atau hasil tahu seseorang terhadap objek melalui indera yang dimilikinya (mata, hidung, telinga, dan sebagainya). Selain itu, Notoatmodjo juga menuturkan bahwa terdapat 6 (enam) tingkatan pengetahuan, yaitu: tahu (know), memahami (comprehention), aplikasi (application), analisis (analysis), sintesis (sinthesis), evaluasi (evaluation).

\section{Sikap Remaja}

Menurut Ahmadi (2007) sikapad alah kesiapan merespon yang bersifat positif atau negatif terhadap objek atau situasi secara konsisten. Menurut Allport (1954) sikap terdiri dari 3 (tiga) komponen, yaitu:

1. Kepercayaan atau keyakinan, ide, dan konsep terhadap objek, artinya bagaimana keyakinan dan pendapat atau pemikiran seseorang terhadap objek.

2. Kehidupan emosional atau evaluasi terhadap objek, artinya bagaimana penilaian (terkandung di dalamnya faktor emosi) orang tersebut terhadap objek.

3. Kecenderungan untuk bertindak (tend to behave), artinya sikap adalah merupakan komponen yang mendahului tindakan atau perilaku terbuka. Sikap adalah ancang-ancang untuk bertindak atau berperilaku terbuka (tindakan).

\section{KERANGKA BERPIKIR}

Kerangka berpikir yang baik akan menjelaskan secara teoritis pertautan antar variabel yang akan diteliti. Jadi secara teoritis perlu dijelaskan hubungan antar variabel independen dan dependen, maka secara ringkas kerangka pemikiran yang mendasari penelitian ini diilustrasikan ke dalam bagan Gambar 1 . 


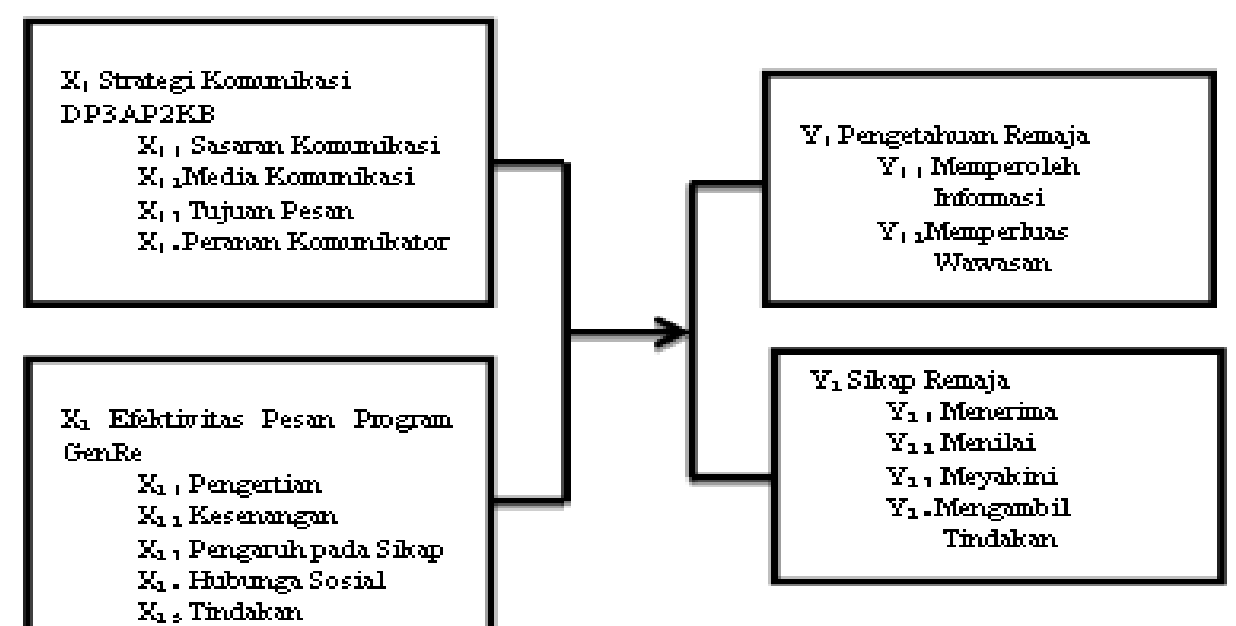

Gambar 1 Kerangka berfikir penelitian

\section{METODE PENELITIAN}

Jenis penelitian menggunakan metode penelitian asosiatif dengan pendekatan kuantitatif. Sugiyono (2015) metode penelitian kuantitatif dapat diartikan sebagai metode penelitian yang berlandaskan pada filsafat positivisme, digunakan untuk meneliti pada populasi atau sampel tertentu, pengumpulan data menggunakan instrumen penelitian, analisis data bersifat kuantitatif atau statistik, dengan tujuan untuk menguji hipotesis yang telah ditetapkan.

\section{Populasi dan Sampel}

Sugiyono (2012) populasi adalah wilayah generalisasi yang terdiri atas: objek/subjek yang mempunyai kualitas dan karakteristik tertentu yang ditetapkan oleh peneliti untuk dipelajari dan kemudian ditarik kesimpulannya.

Populasi dalam penelitian ini adalah remaja Kecamatan Caringin dengan jumlah 38.405 remaja. Dari populasi tersebut dapat ditarik sampel, untuk mendapatkan besaran jumlah sampel dalam penelitian ini menggunakan rumus Yamane sebagai berikut

$$
\mathrm{n}=\frac{\mathrm{N}}{\mathrm{N} \mathrm{d}^{2}+1}
$$

Keterangan :

n : Ukuran sampel

$\mathrm{N}$ : Populasi

d :Tingkat kesalahan ditetapkan secara sengaja sebesar $10 \%$.

\section{Teknik Analisis Data}

Penelitian ini menggunakan rumus WMS.

$\sum \mathrm{f}(\mathrm{x})=\mathrm{M} / \mathrm{n}$

$\mathrm{M}=$ Perolehan angka kriteria penafsiran

$\mathrm{f}=$ Frekuensi jawaban

$\mathrm{x}=$ Pembobotan skala nilai

$\mathrm{n}=$ Jumlah responden

Kemudian dianalisis dengan menggunakan rumus Rank Spermenuntuk mengetahui sejauh mana pengaruh strategi komunikasi dan efektivitas pesan Program GenRe terhadap pengetahuan dan sikap remaja di Kecamatan Caringin. 


\section{HASIL DAN PEMBAHASAN}

\section{Analisis Pengaruh Strategi Komunikasi dengan Pengetahuan Remaja}

Berdasarkan hasil analisis antara variabel Strategi Komunikasi (X1) dengan Pengetahuan Remaja (Y1) dapat disimpulkan bahwa nilai koefisien korelasi Rank Spearmanantara variabel strategi komunikasi dengan variabelpengetahuan remaja sebesar $0,370^{* *}$ dengan arah positif. Artinya semakin ideal pelaksanaan strategi komunikasi DP3AP2KB Kabupaten Bogor dalam melakukan sosialisasi maka akan berpengaruh besar terhadap bertambahnya pengetahuan remaja.

Interpretasi terhadap koefisien korelasi tingkat hubungan variabel strategi komunikasi dengan pengetahuan remaja termasuk pada hubungan kategori yang rendah. Namun, dapat dilihat angka koefesien korelasi positif menunjukan hubungan yang positif.

Besarnya kontribusi variabel Strategi Komunikasi yang dilakukan DP3AP2KB Kabupaten Bogor melalui sosialisasi pesan Program GenRe terhadap variabel Pengetahuan Remaja Kecamatan Caringin sebesar $14 \%$ dan kontribusi faktor lain adalah sebesar $86 \%$.

\section{Analisis Pengaruh Strategi Komunikasi dengan Sikap Remaja}

Hasil analisis antara variabel Strategi Komunikasi (X1) dengan Sikap Remaja (Y2) dapat disimpulkan bahwa nilai koefisien korelasi Rank Spearmanantara variabel strategi komunikasi dengan variabel sikap remaja sebesar $0,321^{* *}$ dengan arah positif. Artinya semakin ideal pelaksanaan strategi komunikasi DP3AP2KB Kabupaten Bogor dalam melakukan sosialisasi maka akan berpengaruh besar terhadap perubahan sikap remaja kearah yang lebih baik.

Berdasarkan interpretasi terhadap koefisien korelasi tingkat hubungan variabel Strategi Komunikasi dengan Sikap Remaja termasuk pada hubungan kategori yang rendah. Namun, dapat dilihat angka koefesien korelasi positif menunjukan hubungan yang positif. Artinya ada hubungan antara strategi komunikasi yang dilakukan oleh DP3AP2KB Kabupaten Bogor.

Besarnya kontribusi variabel Strategi Komunikasi yang dilakukan DP3AP2KB Kabupaten Bogor melalui sosialisasi pesan Program GenRe terhadap variabel Sikap Remaja Kecamatan Caringin sebesar 11\% dan kontribusi faktor lain adalah sebesar $89 \%$.

\section{Analisis Pengaruh Efektivitas Pesan dengan Pengetahuan Remaja}

Berdasarkan hasil analisis antara variabel Efektivitas Pesan Program GenRe (X2) dengan variabel Pengetahuan Remaja (Y1) dapat disimpulkan bahwa nilai koefisien korelasi Rank Spearmanantara variabel efektivitas pesan Program GenRe dengan variabel pengetahuan remaja sebesar 0,424** dengan arah positif. Artinya semakin efektif sosialisasi pesan Program GenRe yang dilakukan oleh DP3AP2KB Kabupaten Bogor maka akan berpengaruh besar terhadap bertambahnya pengetahuan remaja.

Berdasarkan interpretasi terhadap koefisien korelasi tingkat hubungan variabel Efektivitas Pesan Program GenRe dengan Pengetahuan Remajatermasuk pada hubungan kategori yang sedang.

Besarnya kontribusi variabel Efektivitas Pesan Program GenRe yang disosialisasikan oleh DP3AP2KB Kabupaten Bogor terhadap variabel Pengetahuan Remaja Kecamatan Caringin sebesar 18\% dan kontribusi faktor lain adalah sebesar $82 \%$.

\section{Analisis Pengaruh Efektivitas Pesan dengan Sikap Remaja}

Hasil analisis antara variabel Efektivitas Pesan Program GenRe (X2) dengan Sikap Remaja (Y2) dapat disimpulkan bahwa nilai koefisien korelasi Rank Spearmanantara 
variabel Efektivitas Pesan Program GenRe dengan Sikap Remaja sebesar 0,342** dengan arah positif. Artinya semakin efektif sosialisasi pesan Program GenRe yang dilakukan oleh DP3AP2KB Kabupaten Bogor maka akan berpengaruh besar terhadap perubahan sikap remaja kearah yang lebih baik.

Berdasarkan tabel interpretasi terhadap koefisien korelasi tingkat hubungan variabel Efektivitas Pesan Program GenRe dengan Sikap Remaja termasuk pada hubungan kategori yang rendah. Namun, dapat dilihat angka koefesien korelasi positif menunjukan hubungan yang positif. Artinya ada hubungan antara variabel Efektivitas Pesan Program GenRe yang disosialisasikan oleh DP3AP2KB Kabupaten Bogor dengan variabelSikap Remaja meskipun keeratan hubungannya berada dikategori rendah. Besarnya kontribusi variabel Efektivitas Pesan Program GenRe yang disosialisasikan oleh DP3AP2KB Kabupaten Bogor terhadap variabel Sikap Remaja Kecamatan Caringin sebesar $12 \%$ dan kontribusi faktor lain adalah sebesar $88 \%$.

\section{Analisis Pengaruh Strategi Program terhadap Pengetahuan dan Sikap Remaja}

Hasil analisis menggunakan Rank Spearman diketahui bahwa besarnya hubungan antara variabel independen (Strategi Komunikasi dan Efektivitas Pesan Program GenRe) terhadap variabel dependen (Pengetahuan dan Sikap Remaja) yang dihitung dengan koefisien korelasi adalah 0,412**. Hal ini menunjukkan pengaruh yang sedang. Dapat dilihat pula kontribusi atau sumbangan secara simultan variabel Strategi Komunikasi dan Efektivitas Pesan Program GenRe terhadap Pengetahuan dan Sikap Remaja adalah 17 $\%$. Dengan demikian dapat disimpulkan bahwa Strategi Komunikasi dan Efektivitas Pesan Program GenRe yang disosialisasikan oleh DP3AP2KB Kabupaten Bogor memiliki pengaruh terhadap
Pengetahuan dan Sikap Remaja di Kecamatan Caringin.

\section{KESIMPULAN DAN IMPLEMENTASI}

\section{Kesimpulan}

1. Strategi Komunikasi yang dilakukan oleh DP3AP2KB Kabupaten Bogor dalam mewujudkan remaja yang berkualitas yaitu dengan mensosialisasikan pesan Program Generasi Berencana atau GenRe kepada remaja. Setelah dilakukan penelitian, maka diperoleh hasil bahwa strategi komunikasi yang dilakukan memiliki pengaruh yang sangat nyata terhadap pengetahuan dan sikap remaja di Kecamatan Caringin.

2. Efektivitas pesan yang disosialisasikan oleh DP3AP2KB Kabupaten Bogor pada sebuah Program GenRe memiliki pengaruh yang sangat nyata terhadap pengetahuan dan sikap remaja di Kecamatan Caringin.

3. Pengetahuan dan sikap remaja di Kecamatan Caringin dipengaruhi oleh strategi komunikasi dan efektivitas pesan Program GenRe yang disosialisasikan oleh DP3AP2KB Kabupaten Bogor.

4. Strategi Komunikasi dan Efektivitas Pesan Program GenRe yang disosialisasikan oleh Dinas Pemberdayaan Perempuan dan Perlindungam Anak, Pengendalian Penduduk dan Keluarga Berencana Kabupaten Bogor memiliki pengaruh hubungan yang positif (sangat nyata) terhadap pengetahuan dan sikap remaja di Kecamatan Caringin.

\section{Implementasi}

1. Penggunaan media komunikasi yang dipilih oleh DP3AP2KB Kabupaten 
Bogor sebagai salah satu faktor dalam menjalankan strategi komunikasi dengan cara mensosialisasikan pesan Program GenRe melalui leaflet dan media online facebook sudah efektif. Namun akan lebih efektif jika media lain pun ikut digunakan, seperti akun Whatsapp, Instagram atau radio dan televisi.

2. Penyampaian pesan Program GenRe sebaiknya dilakukan secara berulangulang. Hal ini bisa dilakukan dengan dibuatnya iklan berjenis layanan masyarakat yang disampaikan tidak hanya melalui radio, namun juga melalui televisi. Sehingga remaja akan dengan mudah mendapatkan informasi mengenai isi pesan dalam Program Generasi Berencana.

\section{DAFTAR PUSTAKA}

Ahmadi A. 2007. Psikologi Sosial. Jakarta: Rineka Cipta.

Anwar A. 1984. Strategi Komunikasi: Suatu Pengantar Ringkas. Bandung: Armico.

Cangara H. 2013. Pengantar Ilmu Komunikasi. Jakarta: PT. Raja Graffindo Persada.

Effendy OU. 2009. Ilmu Komunikasi Teori dan Praktek. Bandung: PT. Remaja Rosdakarya.

Notoatmodjo S. 2005. Metodologi Penelitian Kesehatan. Jakarta: PT. Rineka

Steers RM. 1985. Efektivitas Organisasi. Jakarta: Erlangga.

Sugiyono. 2008. Metode Penelitian Kuantitatif, Kualitatif dan R\&D. Bandung: Penerbit Alfabeta

2012. Metode Penelitian Administrasi. Bandung: Penerbit Alfabeta
2015. Metode Penelitian Kuantitatif, Kualitatif dan R\&D. Bandung: Penerbit Alfabeta

Tubbs SL. 2010. Human Communication: Prinsip-Prinsip Dasar. Bandung: PT. Remaja Rosdakarya.

Purwanto N. 2000. Psikologi Pendidikan. Bandung: Remaja Rosdakarya.

Widjaja AW. 1988. Ilmu Komunikasi: Pengantar Studi. Jakarta: PT. Bina Aksara

Widjaya AT. 1993. Manajemen Suatu Pengantar. Jakarta: Rineka Cipta Jaya. 